\title{
The Effect of Aging on the Mature Albino Rat Testis, A morphometric Study
}

\author{
Basima A. AL-sarraj \\ Department of Anatomy \\ College of Medicine \\ Mosul University \\ E-mail basimaalsarrj@yahoo.com
}

(Received 6/7/2009; Accepted 5/4/2010)

\begin{abstract}
Two groups of healthy mature male albino rats, fed ad libitum, were used in this study, each group of ten animals, the age of animals in the first group was 4 months and $130-$ $190 \mathrm{~g}$ in weight, and the age of animals in the second group was 12 months and $240-300 \mathrm{~g}$ in weight.

After fixation of the right testis which removed from all animals, 5 blocks were prepared from each testis and one random section from each block was stained with Hematoxylin and Eosin.

The diameter of the seminiferous tubules, its lumen and the thickness of the germinal epithelium, and the number of spermatogonia, spermatocytes and the Leydig cells were estimated using a visopan projecting microscope to study the effect of aging on the histology of the testis.

The study showed no changes in the diameter and lumen of seminiferous tubules, and in the thickness of the germinal epithelium, while there was a significant negative changes in the number of spermatogonia, spermatoytes and Leydig cells between the animals of the two groups.

These findings reflect the correlation between aging and testis histological changes which may affect the sexual performance in males.

\section{تأثير فهم الهمر عل خصية الجرذ الأبيض البالغ، درلسةقيلسيقشكليه}

\section{الملخص}

لمتعهل في البحث مجموعتلن من نكور الجرذان البيضاء البالغة، تحتوي ك لـ مجموء ـة عل ق 10

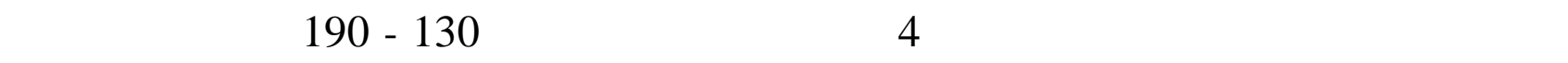
في المجموعة الثانية 12شهر ووزنها يتراوح مابين 240 - 300 غم. بعد شتبيت الخصى اليمن للجرذان من

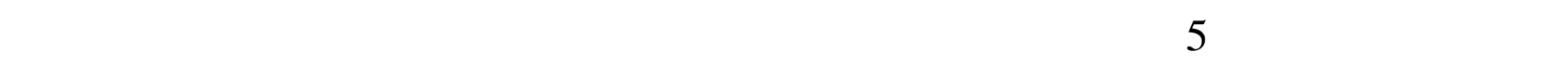
بصبغة الهيماتوكسلين والايوسين .
\end{abstract}




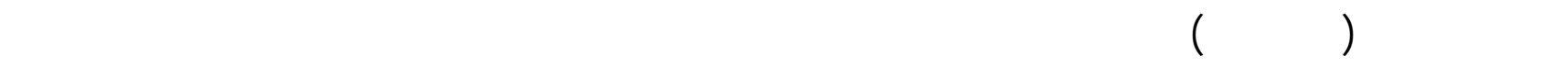

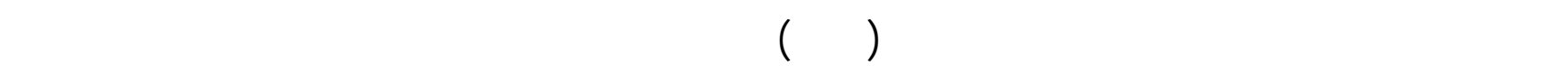
لأنسجة وخلايا الخصية. لظاهرت نتائج البمث عدم وجود لختلاف في قطر وتجويف النبيبت المنوية وسمك الظهارة المنوية، ووج -ود

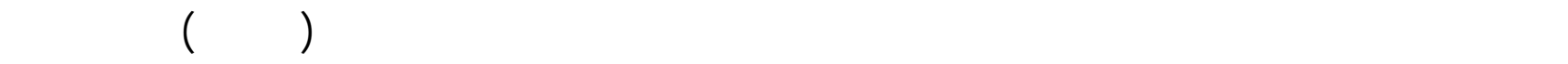
المجموعتن. هذه التتائج تعكس ارتبط بين الققم بالعمر والتغيرات النسيجيه المنويه والتي قد تؤثر على الاداء الجنسي في الذكور. 